\title{
PENGARUH PEMBERIAN EKSTRAK BUNGA PEPAYA (Carica papaya $L$ ) TERHADAP KADAR HIGH DENSITY LIPOPROTEIN (HDL) DAN LOW DENSITY LIPOPROTEIN (LDL) DARAH TIKUS (Rattus norvegicus) GALUR Sprague dawley JANTAN YANG DIBERI DIET TINGGI LEMAK
}

\author{
Dita Fitriani ${ }^{1}$, Hetti Rusmini ${ }^{2}$, Yulia Wildani Marek ${ }^{3}$
}

1Departemen Fisiologi, Fakultas Kedokteran, Universitas Malahayati
2Departemen Farmakologi, Fakultas Kedokteran, Universitas Malahayati
${ }^{3}$ Program Studi Kedokteran, Fakultas Kedokteran, Universitas Malahayati

\begin{abstract}
The Influence of Papaya Flower Extract (Carica papaya L) on High Density Lipoprotein (HDL) and Low Density Lipoprotein (LDL) Blood Male Rats (Rattus norvegicus) var. Sprague dawley Given a High-Fat Diet. Hyperlipidemia is a pathological condition due to abnormalities in lipid metabolism characterized by increased lipid fraction in the blood. Papaya flowers contain compounds that are able to maintain cholesterol levels within normal limits because they contain flavanoid and tannin that have a function as antioxidants. In this study, rats were used as experimental animals to determine the effect of papaya flower extract on blood HDL and LDL levels of rats given a high-fat diet. This study used 25 male Sprague dawley rats aged 12-16 weeks weighing 200-250 g, with pre and post test with control group design. Rats were divided into 5 groups; a group of rat that were only given a standard diet $(K)$, a group of rat that were given a highfat diet $(\mathrm{KN})$, a group of rat given a high-fat diet and papaya flower extract 31 $\mathrm{mg} / \mathrm{kgBW}(\mathrm{P} 1)$, a group of rat that were given a high-fat diet and extract papaya flowers $62 \mathrm{mg} / \mathrm{kgBW}$ (P2), and a group of rat given a high-fat diet and papaya flower extract $125 \mathrm{mg} / \mathrm{kgBW}$ (P3). The results showed that administration of papaya flower extract at a dose of $31 \mathrm{mg} / \mathrm{kgBW}, 62 \mathrm{mg} / \mathrm{kgBW}$ and $125 \mathrm{mg} / \mathrm{kgBW}$ was able to increase the mean HDL levels and reduce the mean LDL levels of rat blood significantly $(p<0.05)$. However, the higher dose had no effect on levels of HDL and LDL.
\end{abstract}

Keywords : Papaya flower extract, HDL, LDL, high fat diet.

\begin{abstract}
Abstrak: Pengaruh Pemberian Ekstrak Bunga Pepaya (Carica papaya L) Terhadap Kadar High Density Lipoprotein (HDL) dan Low Density Lipoprotein (LDL) Darah Tikus (Rattus norvegicus) Galur Sparague dawley Jantan yang Diberi Diet Tinggi Lemak. Hiperlipidemia merupakan suatu keadaan patologis akibat kelainan metabolisme lipid yang ditandai dengan peningkatan fraksi lipid di dalam darah. Bunga pepaya mengandung senyawa yang mampu mempertahankan kadar kolesterol dalam batas normal karena mengandung senyawa flavanoid dan tanin yang berperan sebagai antioksidan. Pada penelitian ini digunakan tikus sebagai hewan coba untuk mengetahui pengaruh pemberian ekstrak bunga pepaya (Carica papaya $L$ ) terhadap kadar HDL dan LDL darah tikus yang diberi diet tinggi lemak. Penelitian ini menggunakan 25 ekor tikus Sprague dawley jantan berusia 12-16 minggu dengan berat 200-250 g, dengan pre and post test with control group design. Tikus dibagi menjadi 5 kelompok yaitu; kelompok tikus yang hanya diberi pakan standar $(\mathrm{K})$, kelompok tikus yang diberi diet tinggi lemak $(\mathrm{KN})$, kelompok tikus yang diberi diet tinggi lemak dan ekstrak bunga pepaya $31 \mathrm{mg} / \mathrm{kgBB}$ (P1), kelompok tikus yang diberi diet tinggi lemak dan ekstrak bunga pepaya $62 \mathrm{mg} / \mathrm{kgBB}$ (P2), dan kelompok tikus yang diberi diet tinggi lemak dan ekstrak bunga pepaya $125 \mathrm{mg} / \mathrm{kgBB}$ (P3). Hasil penelitian menunjukkan bahwa pemberian ekstrak bunga pepaya dengan dosis $31 \mathrm{mg} / \mathrm{kgBB}, 62 \mathrm{mg} / \mathrm{kgBB}$ dan 125 mg/kgBB mampu meningkatkan rerata kadar HDL dan menurunkan rerata
\end{abstract}


kadar LDL darah tikus secara signifikan $(p<0,05)$. Namun semakin besar dosis tidak berpengaruh terhadap kadar HDL dan LDL.

Kata kunci : Ekstrak bunga pepaya, HDL, LDL, diet tinggi lemak.

\section{PENDAHULUAN}

Pola makan modern yang banyak mengandung kolesterol, disertai intensitas makan yang tinggi, stres yang menekan sepanjang hari, obesitas serta aktivitas fisik yang rendah membuat kadar kolesterol darah sangat sulit dikendalikan dan dapat menimbulkan hiperlipidemia. Hiperlipidemia merupakan suatu keadaan patologis akibat kelainan metabolisme lipid yang dikenal juga dengan dislipoproteinemia atau gangguan pada lipoprotein. Hiperlipidemia ditandai dengan peningkatan kadar kolesterol total, trigliserida, low density lipoprotein (LDL), serta penurunan kadar high density lipoprotein (HDL) (Adam, 2009; Price et al., 2006). HDL merupakan lipoprotein yang disintesis dan disekresikan oleh hati dan sedikit di epitel usus selama absorbsi lemak. HDL memiliki densitas yang sangat tinggi karena banyak mengandung protein yaitu 1,019 sampai dengan lebih dari $1,210 \mathrm{~g} / \mathrm{mL}$. Konsentrasi protein pada HDL $45-59 \%$, fosfolipid $25-30 \%$, kolesterol 15-20\% dan trigliserida 3\% (Guyton \& Hall, 2007). LDL merupakan bentuk akhir metabolisme VLDL (Very Low Density Lipoprotein) yang berfungsi membawa kolesterol dari hati menuju jaringan. LDL memiliki densitas yang rendah yaitu 1,019-1,063 $\mathrm{g} / \mathrm{mL}$ dengan komposisi protein $21 \%$ dan lipid $79 \%$ (Botham dan Mayes, 2009). Berdasarkan NCEP ATP-III, kadar HDL dalam batas normal sebesar 40-65 $\mathrm{mg} / \mathrm{dl}$ dan kadar LDL normal sebesar $<100 \mathrm{mg} / \mathrm{dL}$.

Penanganan hiperlipidemia bertujuan untuk menurunkan resiko terjadinya penyakit jantung koroner. Terapi farmakologis yang sering digunakan yaitu statin dan fibrat (Handelsman et al., 2017). Selain menggunakan obat, penggunaan bahan alam dapat dijadikan sebagai salah satu alternatif upaya pencegahan. Tanaman yang sudah diteliti dapat menurunkan kadar kolesterol darah yaitu pepaya (Carica papaya L). Bunga pepaya mengandung senyawa flavanoid dan tanin yang mampu mempertahankan kadar kolesterol dalam batas normal (Hassan, 2014; Vita, 2005). Penelitian ini dilakukan untuk mempelajari pengaruh ekstrak bunga pepaya terhadap kadar HDL dan LDL darah tikus yang diberi diet tinggi lemak.

\section{METODE}

Penelitian ini menggunakan metode ekperimental murni dengan pre and post test with control group design. Hewan coba yang digunakan adalah tikus galur Sprague dawley jantan sebanyak 25 ekor berusia 12 16 minggu dengan berat 150-200 gram yang didapat dari Institut Pertanian Bogor (IPB). Tikus dibagi menjadi 5 kelompok yaitu; kelompok tikus yang hanya diberi pakan standar $(\mathrm{K})$, kelompok tikus yang diberi diet tinggi lemak $(K N)$, kelompok tikus yang diberi diet tinggi lemak dan ekstrak bunga pepaya $31 \mathrm{mg} / \mathrm{kgBB}$ (P1), kelompok tikus yang diberi diet tinggi lemak dan ekstrak bunga pepaya $62 \mathrm{mg} / \mathrm{kgBB}$ (P2), dan kelompok tikus yang diberi diet tinggi lemak dan ekstrak bunga pepaya 125 $\mathrm{mg} / \mathrm{kgBB}$ (P3).

Pakan standar berupa Comfeed BR-2 diberikan sebanyak 100 $\mathrm{g} /$ kelompok/hari dan air minum ad libitium. Aklimatisasi tikus selama 7 hari. Setelah aklimatisasi, dilakukan penetapan kadar HDL dan LDL yg ke1. Diet tinggi lemak berupa kuning telur bebek $2 \mathrm{ml} / \mathrm{ekor} / \mathrm{hari}$ yang diberikan secara per oral selama 8 minggu dimulai pada hari ke-8. Pada hari ke-64 dilakukan penetapan kadar HDL dan LDL yang ke-2. Pada hari ke64 sampai dengan hari ke-77 
kelompok tikus P1, P2, dan P3 diberi ekstrak bunga pepaya dengan masing-masing dosis $31 \mathrm{mg} / \mathrm{kgBB}, 62$ $\mathrm{mg} / \mathrm{kgBB}$, dan $125 \mathrm{mg} / \mathrm{kgBB}$ selama 2 minggu. Pada hari ke-77 dilakukan penetapan kadar HDL dan LDL darah tahap 3.

\section{Pembuatan ekstrak bunga pepaya}

Bunga pepaya jantan sebanyak $4 \mathrm{~kg}$ diekstraksi. Ekstraksi bunga pepaya dilakukan di Laboratorium FMIPA Universitas Lampung. Ekstraksi dilakukan dengan metode maserasi menggunakan pelarut etanol $96 \%$ selama 3×24 jam. Selanjutnya ekstrak bunga pepaya disaring menggunakan kertas saring dalam Erlenmeyer $1000 \mathrm{~mL}$. Selanjutnya dievaporasi pada suhu $78^{\circ} \mathrm{C}$, dimasukkan ke dalam oven pada suhu $40^{\circ} \mathrm{C}$ selama 5 jam hingga diperoleh ekstrak kental (Tangkumahat et al., 2017).

\section{Penetapan kadar HDL dan LDL}

Tikus diinjeksi ketamin dengan dosis $0,2 \mathrm{cc} / 100 \mathrm{grBB}$ sebagai anastesi (Fitriani et al., 2016). Sampel darah tikus diambil sebanyak $2 \mathrm{ml}$ melalui pleksus retro orbitalis dengan menggunakan mikrohematokrit setelah tikus dipuasakan selama 12 jam. Sampel darah disentrifuge hingga diperoleh serum darah (Andari dan Rahayuni, 2014). Serum darah kemudian digunakan untuk mengukur kadar HDL dan LDL darah menggunakan metode pengukuran Enzymatic Endpoint Method dengan spektrofotometri
(Kayamori et al., 1999). Penetapan kadar HDL dan LDL darah dilakukan sebanyak 3 kali: pertama yaitu setelah 1 minggu proses aklimatisasi; kedua yaitu setelah 8 minggu pemberian kuning telur 2 ml/ekor/hari; dan ketiga yaitu setelah 2 minggu pemberian ekstrak bunga pepaya. Kadar HDL darah tikus yang normal yaitu $\geq 35 \mathrm{mg} / \mathrm{dl}$ (Schaerfer et al. dalam Hartoyo et al., 2008). Ambang batas normal LDL pada tikus adalah $7-27,2 \mathrm{mg} / \mathrm{dl}$ (Herwiyarirasanta dalam Riesanti et al., 2012).

\section{Analisa data}

Normalitas data diuji dengan uji Shapiro Wilk, homogenitas varian diuji dengan Levene Test. Data yang terdistribusi normal dianalisis dengan one-way ANOVA, dan uji lanjut dengan uji post hoc Tamhane. Sedangkan data yang tidak terdistribusi normal dianalisis dengan menggunakan Kruskal-Wallis diikuti dengan uji post hoc Mann Whitney. Uji Paired T-test digunakan untuk menganalisis perbedaan nilai sebelum dan sesudah diberi perlakuan jika data terdistribusi normal $(p<0,05)$.

\section{HASIL}

\section{Kadar HDL darah}

Kadar HDL darah normal pada tikus yaitu $\geq 35 \mathrm{mg} / \mathrm{dL}$ (Schaerfer et al. dalam Hartoyo et al., 2008). Rerata kadar HDL darah tikus sebelum dan sesudah perlakuan disajikan dalam tabel 1 dibawah ini:

Tabel 1. Hasil analisis uji Paired T-Test Kadar HDL

\begin{tabular}{cccccc}
\hline Kelompok & $\begin{array}{c}\text { Rerata } \\
\text { sesudah tahap } \\
\text { aklimatisasi } \\
(\mathrm{mg} / \mathrm{dL}) \pm \mathrm{SD}\end{array}$ & $\begin{array}{c}P \\
\text { (sebelum } \\
\text { dan } \\
\text { sesudah } \\
\text { diet) }\end{array}$ & $\begin{array}{c}\text { Rerata sesudah } \\
\text { diet tinggi } \\
\text { lemak }(\mathrm{mg} / \mathrm{dL}) \\
\pm \mathrm{SD}\end{array}$ & $\begin{array}{c}P \\
\text { (sebelum } \\
\text { dan } \\
\text { sesudah } \\
\text { ekstrak) }\end{array}$ & $\begin{array}{c}\text { Rerata sesudah } \\
\text { ekstrak bunga } \\
\text { pepaya }(\mathrm{mg} / \mathrm{dL}) \\
\pm \mathrm{SD}\end{array}$ \\
\hline $\mathrm{K}$ & $42,2 \pm 2,59$ & $0,002^{*}$ & $33,2 \pm 1,30$ & $0,001^{*}$ & $40,2 \pm 1,30$ \\
\hline $\mathrm{KN}$ & $38,6 \pm 1,34$ & $0,007^{*}$ & $25,8 \pm 5,36$ & $0,027^{*}$ & $18,8 \pm 4,49$ \\
\hline $\mathrm{P} 1$ & $37,6 \pm 4,93$ & $0,010^{*}$ & $28,4 \pm 4,67$ & $0,023^{*}$ & $37 \pm 2$ \\
\hline $\mathrm{P} 2$ & $34,75 \pm 1,89$ & $0,012^{*}$ & $26,75 \pm 12,99$ & $0,008^{*}$ & $37,75 \pm 1,71$ \\
\hline $\mathrm{P} 3$ & $37,2 \pm 4,44$ & $0,018^{*}$ & $28,6 \pm 2,51$ & $0,002^{*}$ & $38,6 \pm 1,82$ \\
\hline
\end{tabular}

Keterangan: $P$ adalah nilai $p$ uji Paired T-Test.

$(*)$ ada perbedaan yang signifikan. 
Berdasarkan tabel 1 diatas, setelah tahap aklimatisasi selama 7 hari, rerata kadar HDL darah tikus dalam batas normal. Kemudian setelah pemberian diet tinggi lemak terjadi penurunan kadar HDL darah tikus pada kelompok yang diberi diet tinggi lemak secara signifikan ( $p$ $<0,05)$. Setelah pemberian ekstrak bunga pepaya pada kelompok P1, P2, dan P3 terjadi peningkatan kadar HDL secara signifikan $(p<0,05)$.

Perbedaan rerata selisih kadar HDL sebelum dan sesudah perlakuan diuji menggunakan One-Way ANOVA didapatkan hasil $p=0,481$ untuk rerata selisih kadar HDL sebelum dan sesudah diberi diet tinggi lemak dan $p$ $=0,452$ untuk rerata selisih kadar HDI sebelum dan sesudah diberi ekstrak bunga pepaya yang menunjukkan tidak ada perbedaan signifikan pada rerata selisih kadar HDL sebelum dan sesudah perlakuan antar kelompok $(p<0,05)$. Perbedaan rerata selisih kadar HDL sebelum dan sesudah perlakuan disajikan dalam gambar 1 dibawah ini:

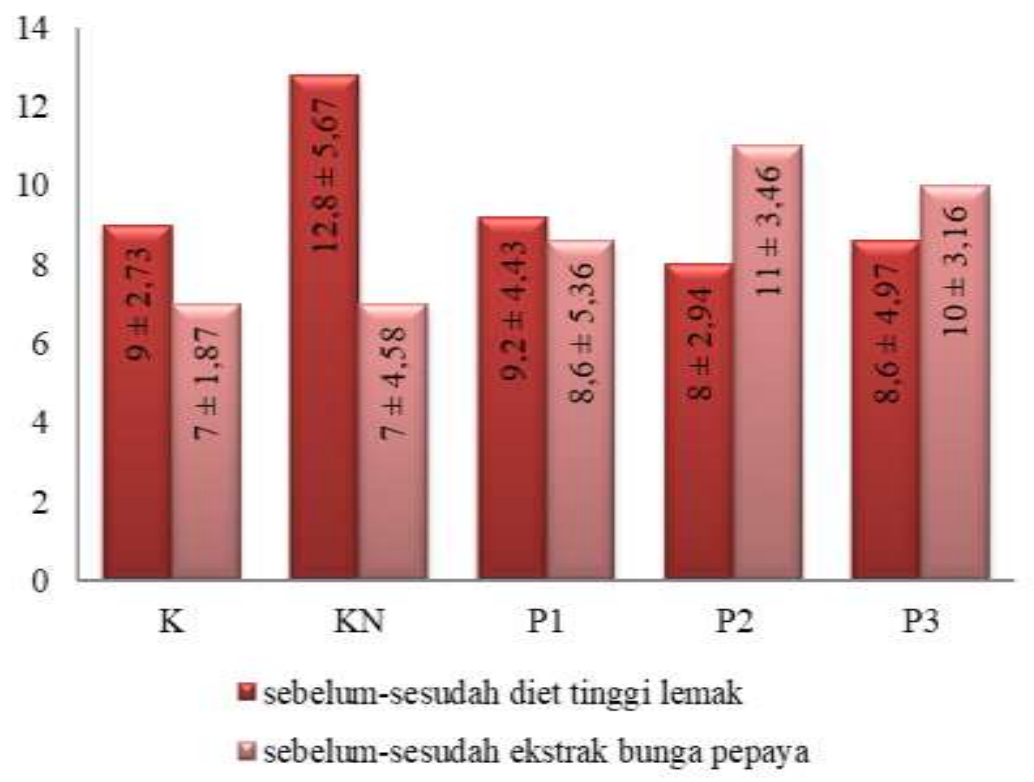

\section{Gambar 1. Grafik nilai rerata selisih kadar HDL sebelum dan sesudah perlakuan}

\section{Kadar LDL darah}

Kadar LDL darah tikus dengan ambang batas normal 7-27,1 $\mathrm{mg} / \mathrm{dL}$ (Herwiyarirasanta dalam Riesanti et al., 2012). Rerata kadar LDL darah tikus sebelum dan sesudah perlakuan disajikan dalam tabel 2 dibawah ini:

Tabel 2. Hasil analisis uji Paired T-Test kadar LDL darah tikus

\begin{tabular}{cccccc}
\hline Kelompok & $\begin{array}{c}\text { Rerata tahap } \\
\text { aklimatisasi } \\
(\mathrm{mg} / \mathrm{dL}) \pm \mathrm{SD}\end{array}$ & $\begin{array}{c}P \\
\text { (sebelum } \\
\text { dan } \\
\text { sesudah } \\
\text { diet) }\end{array}$ & $\begin{array}{c}\text { Rerata sesudah } \\
\text { diet tinggi } \\
\text { lemak }(\mathrm{mg} / \mathrm{dL}) \\
\pm \mathrm{SD}\end{array}$ & $\begin{array}{c}P \\
\text { (sebelum } \\
\text { dan } \\
\text { sesudah } \\
\text { ekstrak) }\end{array}$ & $\begin{array}{c}\text { Rerata sesudah } \\
\text { ekstrak bunga } \\
\text { pepaya }(\mathrm{mg} / \mathrm{dL}) \\
\pm \mathrm{SD}\end{array}$ \\
\hline $\mathrm{K}$ & $25 \pm 4,18$ & 0,509 & $23,8 \pm 2,59$ & 0,612 & $25 \pm 4,18$ \\
\hline $\mathrm{KN}$ & $16 \pm 2,24$ & $0,000^{*}$ & $30 \pm 1,58$ & $0,008^{*}$ & $34,6 \pm 2,41$ \\
\hline $\mathrm{P} 1$ & $20,6 \pm 7,16$ & $0,021^{*}$ & $31,4 \pm 2,07$ & $0,005^{*}$ & $21,8 \pm 3,83$ \\
\hline $\mathrm{P} 3$ & $15,5 \pm 2,52$ & $0,001^{*}$ & $29,75 \pm 2,22$ & $0,006^{*}$ & $19,25 \pm 2,63$ \\
\hline $\mathrm{K} 3$ & $11,8 \pm 3,96$ & $0,000^{*}$ & $31 \pm 2,12$ & $0,001^{*}$ & $16,8 \pm 2,59$ \\
\hline
\end{tabular}

Keterangan: $P$ adalah nilai $p$ uji Paired T-Test, $\left({ }^{*}\right)$ ada perbedaan yang signifikan. 
Berdasarkan tabel 2 diatas, setelah tahap aklimatisasi selama 7 hari, rerata kadar LDL darah tikus dalam batas normal. Kemudian setelah pemberian diet tinggi lemak terjadi peningkatan kadar LDL darah tikus pada kelompok yang diberi diet tinggi lemak secara signifikan ( $p$ $<0,05)$. Setelah pemberian ekstrak bunga pepaya pada kelompok P1, P2, dan P3 terjadi penurunan kadar LDL secara signifikan $(p<0,05)$.
Perbedaan rerata selisih kadar LDL sebelum dan sesudah diberi diet tinggi lemak diuji menggunakan OneWay ANOVA didapatkan hasil $p=$ 0,000 yang menunjukkan adanya perbedaan signifikan pada rerata kadar LDL sebelum dan sesudah diberi diet tinggi lemak antar kelompok $(p<0,05)$. Setelah diuji One-Way ANOVA, dilakukan uji post hoc Tamhane dengan hasil pada gambar 2 dibawah ini:

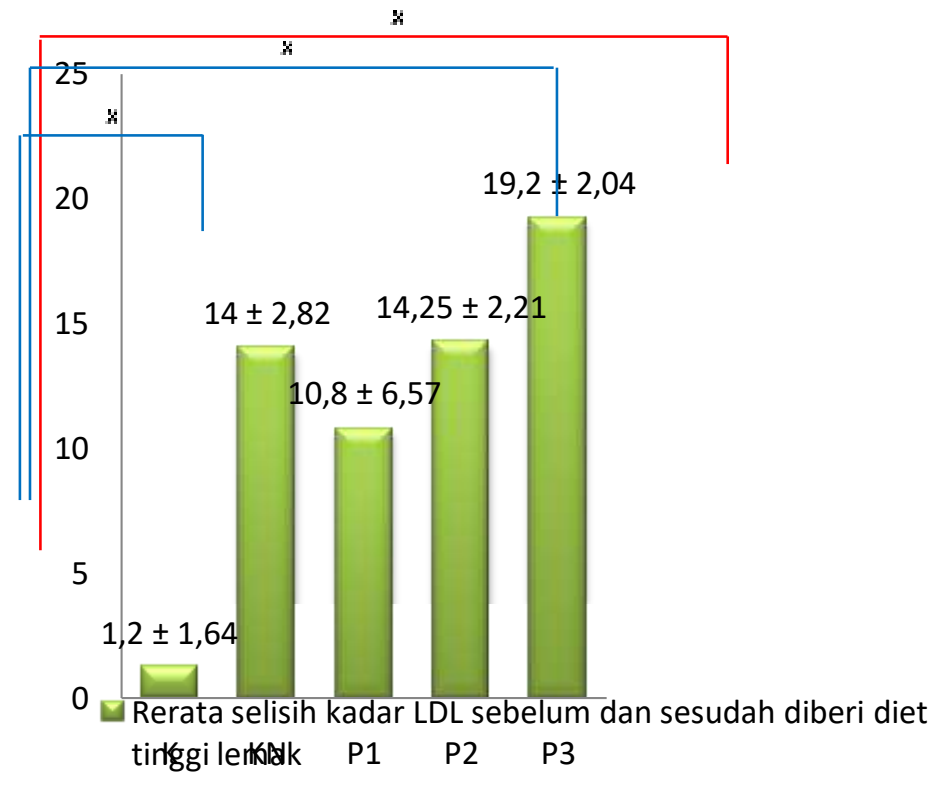

\section{Gambar 2. Grafik hasil analisis uji post hoc Tamhane rerata selisih kadar LDL sebelum dan sesudah diberi diet tinggi lemak}

Keterangan : Tanda (x) menunjukkan adanya perbedaan yang signifikan.

Perbedaan rerata selisih kadar LDL sebelum dan sesudah diberi ekstrak bunga pepaya diuji menggunakan Kruskal Wallis karena data tidak terdistribusi normal ( $p$ $>0,05)$ dengan hasil $p=0,007$ yang menunjukkan terdapat perbedaan yang signifikan pada rerata selisih kadar LDL sebelum dan sesudah diberi ekstrak bunga pepaya antar kelompok $(p<0,05)$. Kemudian diuji post hoc Mann Whitney untuk mengetahui kelompok manakah yang mengalami perbedaan signifikan dengan hasil pada gambar 3 dibawah ini: 


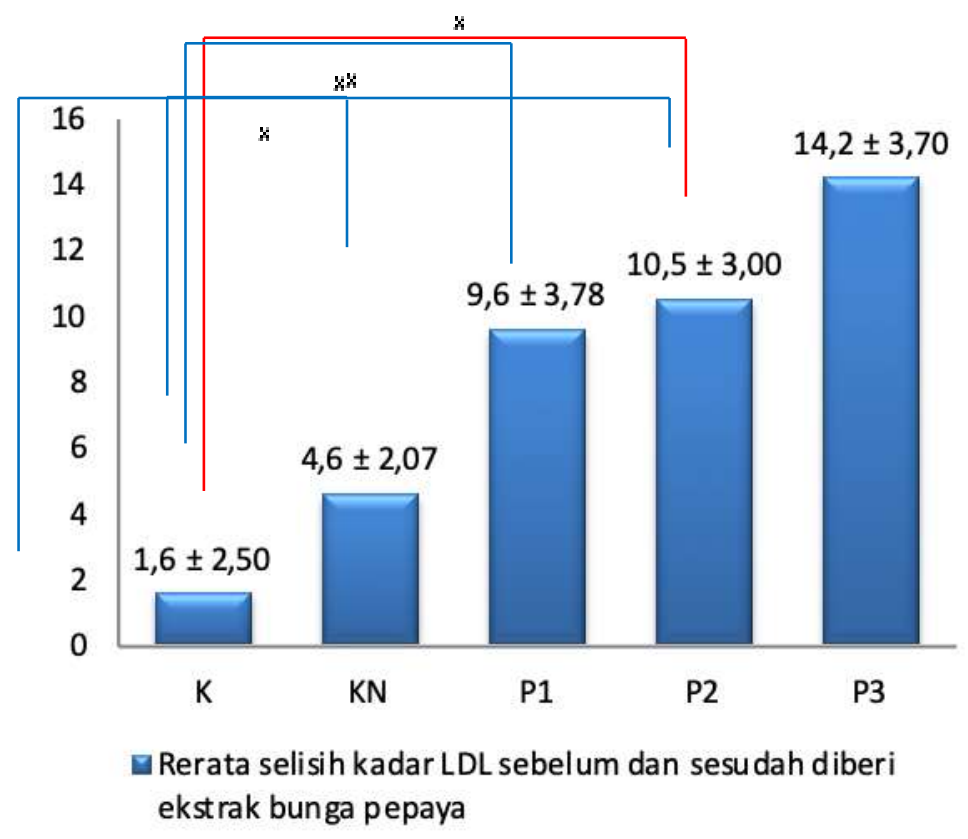

Gambar 3. Grafik hasil analisis uji post hoc Mann Whitney rerata selisih kadar LDL sebelum dan sesudah diberi ekstrak bunga pepaya

Keterangan : Tanda (x) menunjukkan adanya perbedaan yang signifikan.

\section{PEMBAHASAN \\ Pengaruh pemberian ekstrak bunga pepaya (Carica papaya $L$ ) terhadap kadar LDL darah tikus yang diberi diet tinggi lemak \\ Berdasarkan penelitian yang} telah dilakukan, kadar LDL darah tikus menunjukkan hasil yang bervariasi. Setelah tahap aklimatisasi selama 1 minggu, rerata kadar LDL darah tikus dalam batas normal.

Pemberian diet tinggi lemak berupa kuning telur bebek yang mengandung $17 \mathrm{~g}$ protein, $35 \mathrm{~g}$ lemak, dan 884 kolesterol/100 g menyebabkan peningkatan kadar LDL darah yang signifikan $(p<0,05)$ pada kelompok KN, P1, P2, dan P3. Terdapat perbedaan yang signifikan antar kelompok pada rerata selisih peningkatan kadar LDL sebelum dan sesudah diberi diet tinggi lemak ( $p$ $<0,05)$. Dewi dan Probosari (2013) dalam penelitiannya juga mengatakan bahwa pemberian kuning telur bebek mampu meningkatkan kadar LDL. Selain itu, dalam penelitian Heriansyah (2013) juga mengatakan bahwa pemberian diet tinggi lemak selama 8 minggu mampu meningkatkan kadar LDL secara signifikan. Hal ini disebabkan karena lemak yang berasal dari makanan kaya akan trigliserida. Peningkatan kadar trigliserida yang berasal dari lemak eksogen menyebabkan peningkatan pembentukan VLDL, IDL, serta pembentukan LDL yang berasal dari IDL juga akan meningkat (Harsa, 2014).

Penanganan hiperlipidemia bertujuan untuk menurunkan resiko terjadinya penyakit jantung koroner. Selain menggunakan obat-obatan, penggunaan bahan alam dapat dijadikan sebagai salah satu alternatif upaya pencegahan. Pada penelitian ini digunakan ekstrak bunga pepaya (Carica papaya L) karena mengandung senyawa yang mampu mempertahankan kadar kolesterol dalam batas normal yaitu flavanoid dan tanin (Hassan, 2014; Vita, 2005). Flavanoid berperan sebagai antioksidan yang mampu menangkal radikal bebas dan menurunkan 
kepekaan LDL terhadap pembuluh darah sehingga menurunkan risiko terjadinya aterosklerosis (Vita, 2005). Flavanoid juga dapat menghambat enzim HMG-CoA reduktase sehingga pembentukan kolesterol LDL akan menurun (Artha et al., 2017). Tanin berfungsi sebagai antioksidan dengan cara menurunkan oksidasi lemak sehingga mampu mencegah terjadinya stress oksidatif (Witosari dan Widyastuti, 2014). ZetinaEsquivel et al. (2015) dalam penelitiannya menjelaskan bahwa pemberian ekstrak daun pepaya yang juga mengandung flavanoid dan tanin dengan dosis 31, 62, dan 125 $\mathrm{mg} / \mathrm{kgBB}$ mampu menurunkan kadar LDL dalam serum secara signifikan. Selain itu, dalam penelitian Agustina dan Murwani (2013) mengatakan bahwa pemberian jus biji pepaya mampu menurunkan rasio kadar LDL:HDL tetapi tidak bermakna.

$$
\text { Dalam penelitian ini, }
$$

pemberian ekstrak bunga pepaya pada tikus hiperlipidemia selama 2 minggu mampu menurunkan rerata kadar LDL secara signifikan ( $p$ $<0,05)$. Rerata selisih penurunan kadar LDL sebelum dan sesudah diberi ekstrak bunga pepaya terdapat perbedaan yang signifikan antar kelompok $(p<0,05)$. Rerata selisih dari yang tertinggi sampai terendah yaitu P3 $(14,2 \mathrm{mg} / \mathrm{dL}), \quad \mathrm{P} 2 \quad(10,5$ $\mathrm{mg} / \mathrm{dL}), \quad \mathrm{P} 1 \quad(9,6 \mathrm{mg} / \mathrm{dL}) \quad \mathrm{KN}(4,6$ $\mathrm{mg} / \mathrm{dL})$ dan $\mathrm{K}(1,6 \mathrm{mg} / \mathrm{dL})$. Hal ini menunjukkan bahwa semakin besar dosis ekstrak bunga pepaya yang diberikan, maka semakin besar penurunan kadar LDL darah.

\section{Pengaruh pemberian ekstrak bunga pepaya (Carica papaya $L$ ) terhadap kadar HDL darah tikus yang diberi diet tinggi lemak}

Berdasarkan penelitian yang

telah dilakukan, kadar HDL darah tikus menunjukkan hasil yang bervariasi. Setelah tahap aklimatisasi selama 7 hari, rerata kadar HDL darah tikus dalam batas normal $(\geq 35$ $\mathrm{mg} / \mathrm{dL}$ ). Namun pada kelompok P2 rerata kadar HDL kurang dari normal
$(34,75 \mathrm{mg} / \mathrm{dL})$. Kadar HDL kelompok kontrol setelah tahap pemberian diet tinggi lemak juga mengalami penurunan. Hal ini dapat disebabkan karena kemungkinan sebelum tikus di aklimatisasi, tikus mengkonsumsi pakan standar yang lebih banyak dibanding dengan kelompok lain. Selain itu, penempatan tikus dalam lingkungan yang baru dapat mempengaruhi penurunan kadar HDL. Faktor stres pada hewan coba yang dapat terjadi pada saat penelitian seperti cara pemegangan, pengambilan darah, pengukuran berat badan, penyondean, dan kondisi kebersihan kandang (Balcombe et al., 2004). Stres mampu memicu peningkatan hormon katekolamin (epinefrin dan norepinefrin) dan glukokortikoid (kortisol). Katekolamin merangsang jaringan adiposa untuk melepaskan asam lemak bebas ke sirkulasi. Selain itu, norepinefrin akan menstimulasi reseptor $\beta$-adrenergik pada jaringan adiposa. Hal ini menyebabkan konsentrasi HDL menurun serta kadar LDL meningkat. Kortisol dan asam lemak bebas merangsang sekresi VLDL, sehingga kadar LDL akan meningkat (Adeniran, 2011).

Penetapan kadar HDL setelah tahap pemberian diet tinggi lemak terjadi penurunan kadar HDL darah yang signifikan $(p<0,05)$. Hal ini dikarenakan kadar LDL yang meningkat menyebabkan terjadinya gangguan keseimbangan penyimpanan dan pengangkutan kolesterol di jaringan perifer. Peningkatan penyimpanan kolesterol eksogen di jaringan perifer menyebabkan penurunan konsentrasi HDL (Harsa, 2014). Namun rerata selisih penurunan kadar HDL sebelum dan sesudah diberi diet tinggi lemak tidak menunjukkan adanya perbedaan secara signifikan $(p>0,05)$. Fitriarini et al. (2014) dalam penelitiannya mengatakan bahwa dengan konsumsi lemak yang tinggi terutama lemak jenuh dapat menurunkan kadar HDL. Penelitian yang dilakukan Heriansyah (2013) juga mengatakan bahwa 
pemberian diet tinggi lemak selama 8 minggu mampu menurunkan kadar HDL secara signifikan.

Dalam penelitian yang dilakukan Fitriarini et al. (2014) mengatakan bahwa flavanoid mampu meningkatkan sintesis apolipoprotein A1. Apoliporotein A1 merupakan apoliporotein utama pembentuk HDL sehingga sintesis kolesterol HDL akan meningkat.

Zetina-Esquivel et al. (2015) dalam penelitiannya menjelaskan bahwa pemberian ekstrak daun pepaya yang juga mengandung flavanoid dan tanin dengan dosis 31, 62, dan $125 \mathrm{mg} / \mathrm{kgBB}$ mampu meningkatkan kadar HDL dalam serum secara signifikan. Sukandar et al. (2009) dalam penelitiannya juga mengatakan bahwa pemberian ekstrak air daun jati yang mengandung flavanoid dan tanin mampu meningkatkan kadar HDL walaupun secara statistik tidak berbeda bermakna.

Pemberian ekstrak bunga pepaya pada tikus hiperlipidemia mampu meningkatkan kadar HDL secara signifikan $(p<0,05)$. Rerata selisih peningkatan kadar HDL sebelum dan sesudah diberi ekstrak bunga pepaya tidak menunjukkan adanya perbedaan secara signifikan $(p>0,05)$. Rerata selisih dari yang tertinggi sampai terendah yaitu $\mathrm{P} 2$ (11 $\mathrm{mg} / \mathrm{dL}), P 3(10 \mathrm{mg} / \mathrm{dL}), P 1(8,6$ $\mathrm{mg} / \mathrm{dL})$, KN (7 $\mathrm{mg} / \mathrm{dL})$, dan $\mathrm{K}$ (7 $\mathrm{mg} / \mathrm{dL}$ ). Hal ini menunjukkan bahwa semakin besar dosis tidak berpengaruh banyak terhadap peningkatan kadar HDL.

\section{KESIMPULAN}

Berdasarkan penelitian yang telah dilakukan, dapat disimpulkan bahwa terdapat pengaruh pemberian ekstrak bunga pepaya terhadap peningkatan kadar HDL dan penurunan kadar LDL darah tikus hiperlipidemia secara signifikan ( $p$ $<0,05)$.

\section{DAFTAR PUSTAKA}

Adam, J.M.F. (2009). Buku Ajar Ilmu Penyakit Dalam Jilid II. Edisi ke6. Jakarta: Pusat Penerbitan Departemen IImu Penyakit Dalam FKUI.

Adam, J.M.F. (2014). Buku Ajar Ilmu Penyakit Dalam Jilid III. Edisi ke-5. Jakarta: Pusat Penerbitan Departemen Ilmu Penyakit Dalam FKUI.

Adeniran, A.S. (2011). Dyslipidemic and Atherogenic Effects of Academic Stress. African J of Biochemistry Research, 5(13), 356-359.

Almatsier, S. (2001). Prinsip Dasar Ilmu Gizi. Jakarta: Gramedia Pustaka Utama.

Agustina, D., \& Murwani, H.R. (2013). Pengaruh Pemberian Jus Biji Pepaya (Carica papaya L) terhadap Rasio Kolesterol LDL:HDL Tikus Sprague dawley Dislipidemia. $J$ of Nutrition College, 2(3), 302-311.

Andari, F., \& Rahayuni, A. (2014). Pengaruh Pemberian Serbuk Biji Labu Kuning (Cucurbita moschata) Terhadap Penurunan Kolesterol Total Tikus Wistar Hiper- kolesterolemia. J of Nutrition College, 3(4), 506-516.

Artha, C., Mustika, A., \& Sulistyawati, S. W. (2017). Pengaruh Ekstrak Daun SingawalangTerhadap Kadar LDL Tikus Putih Jantan Hiperkolesterolemia.eJournal

Kedokteran Indonesia, 5(2), 105-109.

Balcombe, J.P., Barnard, N.D., \& Sandusky, C. (2004). Laboratory Routines Cause Animal Stress. Contemporary Topics, 43(6), 42-51. Biemann, E.L. Aterosklerosis dan Bentuk Arteriosklerosis Lainnya. Dalam: Harrison. (2000). Prinsip-prinsip Ilmu Penyakit Dalam. Edisi ke13. Jakarta: EGC.

Botham, K.M., \& Mayes, P.A. Pengangkutan dan Penyimpanan Lipid. Dalam: Murray, R.K., Granner, D.K., \& Rodwell, V.W. 
(2009). Biokimia Harper. Edisi ke-27. Jakarta: EGC.

Champe, P.C., Harvey, R.A., \& Ferrier, D.R. (2010). Biokimia Ulasan Bergambar. Jakarta: EGC.

Dewi, N. C. P., \& Probosari, E. (2013). Pengaruh Pemberian Ekstrak Kacang Hijau (Phaseolus radiatus) Terhadap Kadar Kolesterol LDL Serum Tikus Hiperkolesterolemia. $J$ of Nutrition College, 2(4), 585-592.

Endrinaldi, E., \& Asterina, A. (2012). Pengaruh Pemberian Ekstrak Pepaya Terhadap Kadar Kolesterol Total, LDL dan HDL Darah Tikus Putih Jantan Hiperkolesterolemia. Majalah Kedokteran Andalas, 36(1), 2938.

Fitriani, D., Meliala, A., \& Agustiningsih, D. (2016). The Effect Of Long-Term High-Fat Diet In Ovariectomized Wistar Rat On Leptin Serum Levels. Jmedical Science, 48(2), 6980.

Fitriarini, S., \& Murwani, H. (2014). Perbedaan Pengaruh Antara Ekstrak dan Rebusan Daun Salam (Eugenia polyantha) dalam Pencegahan Penurunan Kadar Kolesterol HDL pada Tikus Sprague dawley. J of Nutrition College, 3(1), 184-191.

Ginghina, C., Bejan, I., \& Ceck, C. D. (2011). Modern Risk Stratification In Coronary Heart Disease. $J$ of Medicine and Life, 4(4), 377.

Guyton, A.C., \& Hall, J.E. (2007). Buku Ajar Fisiologi Kedokteran. Edisi ke-11. Jakarta: EGC.

Handelsman, Y., Mechanick, J.I., Dagogo, J.S., \& Davidson, J. (2017).

American

Association of Clinical

Endocrinologists and American

College of Endocrinology

Guidelines for Management of Dyslipidemia and Prevention of Cardiovascular Disease. Endocr Pract, 23(4), 479-497.
Harsa, I.M.S. (2014). Efek Pemberian Diet Tinggi Lemak terhadap Profil Lemak Darah Tikus Putih (Rattus norvegicus). J Ilmiah Kedokteran, 3(1), 21-28.

Hartoyo, A., Dahrulsyah., Sripalupi, N., \& Nugroho, P. (2008). Pengaruh Fraksi Karbohidrat Kacang Komak (Lablab purpureus (L) sweet) terhadap Kolesterol dan Malonaldehid Serum Tikus Percobaan yang diberi Ransum Tinggi Kolesterol. J Teknologi dan Industri Pangan, 19(1), 2531.

Hassan, M.N., \& Nikmati, L.A. (2014). Uji Kandungan Flavonoid danPerbandingan Aktivitas Antioksidan pada Ekstrak Etanol Simplisia Bunga Pepaya Gantung saat Kuncup dan Mekar. J Skrining Bioaktif, 1(1), 7.

Heriansyah, T. (2013). Pengaruh Berbagai Durasi Pemberian Diet Tinggi Lemak Terhadap Profil Lipid Tikus Putih (Rattus norvegicus Strain Wistar) Jantan. J Kedokteran Syiah Kuala, 13(3), 144-150.

Heryani, R. (2016). Pengaruh Ekstrak Buah Naga Merah Terhadap Profil Lipid Darah Tikus Putih Hiperlipidemia. J IPTEKS Terapan, 10, 8-17.

Jim, E. L. (2013). Metabolisme Lipoprotein. J Biomedik, 5(3).

Kayamori, Y., Hatsuyama, H., Tsujioka, T., Nasu, M., \& Katayama, Y. (1999). Endpoint Colorimetric Method For Assaying Total Cholesterol In Serum With Chole sterol Dehydrogenase. Clinical Chemistry, 45(12), 21582163.

Maisarah, A.M., Asmah, R., \& Fauziah, O. (2014). Antioxidant and Anti Proliferative Activities of Different Parts of Carica papaya L. J of Tissue Sci Eng, 5(1), 1-7.

Mayes, P.A. Pengangkutan dan Penyimpanan Lipid. Dalam: Murray, R.K., Granner, D.K., 
Mayes, P.A., \& Rodwell, V.W. (2003). Biokimia Harper. Edisi ke-25. Jakarta: EGC.

Mishra, P. R., Panda, P. K., Korla, A. C., \& Panigrahi, S. (2011). Evaluation of Acute Hypolipidemic Activity Of Different Plant Extracts In Triton WR- 1339 Induced Hyperlipidemia In Albino Rats. Pharmacologyonline, 3, 925-34.

National Institutes of Heart (NIH). (2011). ATP III Guidelines At A Glance Quick Desck Reference.

Oktaviani, H., Martuti, N. K. T., \& Utami, N. R. (2012). Pengaruh Pengasinan Terhadap

Kandungan Zat Gizi Telur Bebek Yang Diberi Limbah Udang. Life Science, 1(2).

Price, S.A., \& Lorraine, M.W. (2006). Patofisiologi Konsep Klinis Proses-Proses Penyakit. Edisi ke-6. Jakarta: EGC.

Rahayu, S., \& Tjitraresmi, A. (2016). Tanaman Pepaya (Carica papaya L) dan Manfaatnya dalam Pengobatan. Farmaka, 14(1), 117.

Riesanti, D.G., Padaga, M.C., \& Herawati. (2012). Kadar HDL, Kadar LDL dan Gambaran Histopatologi Aorta pada Hewan Model Tikus (Rattus norvegicus)

Hiperkolesterolemia dengan Terapi Ekstrak Air Benalu Mangga (Dendrophthoe pentandra). Fakultas Kedokteran Hewan Universitas Brawijaya. Malang.

Sukandar, E.Y., Elfahmi., \& Nurdewi. (2009). Pengaruh Pemberian Ekstrak Air Daun Jati Belanda
(Guazuma ulmifolia lamk) Terhadap Kadar Lipid Darah Pada Tikus Jantan. JKM, 8(2), 102-112.

Syahrullah, R. R., Assa, Y., \& Tiho, M. (2013). Gambaran Kadar High Density Lipoprotein Darah pada Laki-Laki Berusia 40-59 Tahun dengan Indeks Massa Tubuh $\geq$ $23 \mathrm{~kg} / \mathrm{m} 2$. J e-Biomedik, 1(1).

Tangkumahat, F. G., Rorong, J. A., \& Fatimah, F. (2017). Pengaruh Pemberian Ekstrak Bunga dan Daun Pepaya (Carica Papaya L.) terhadap Kadar Glukosa Darah Tikus Wistar (Rattus norvegicus L.) yang Hiperglikemik. J IImiah Sains, 17(2), 143-152.

Vita, J. A. (2005). Polyphenols And Cardiovascular Disease: Effects On Endothelial And Platelet Function. The American Journal of Clinical Nutrition, 81(1), 292S-297S.

Witosari, N., \& Widyastuti, N. (2014). Pengaruh Pemberian Jus Daun Ubi Jalar (Ipomoea batatas (L.) Lam) Terhadap Kadar Kolesterol Total Tikus Wistar Jantan (Rattus norvegicus) yang Diberi Pakan Tinggi Lemak. $J$ of Nutrition College, 3(4), 638-646.

Zetina-Esquivel, A. M., Tovilla-Zárate, C. A., Guzmán-Garcia, C., Rodríguez- Hernández, A., Castell-Rodríguez, A. E., BleCastillo, J. L., ... \& Díaz-Zagoya, J. C. (2015). Effect Of Carica papaya Leaf Extract On Serum Lipids And Liver Metabolic Parameters Of Rats Fed A High Cholesterol Diet. Health, 7(09), 1196. 